\title{
Antibacterial Meroterpenoids from the South China Sea Sponge Dysidea sp.
}

\author{
Xia Zhang, ${ }^{a}$ Hong-Yan Xu, ${ }^{a}$ Ai-Mei Huang, ${ }^{a}$ Lei Wang, ${ }^{a}$ Qiang Wang, ${ }^{a}$ Peng-Yun Cao, ${ }^{a, b}$ and \\ Pei-Min Yang $*, a$ \\ ${ }^{a}$ Department of Pharmacy, People's Hospital of Linzi District; Zibo 255400, P.R. China: and ${ }^{b}$ Department of \\ Pharmacy, Shandong University of Traditional Chinese Medicine; Jinan 250355, P.R. China. \\ Received February 24, 2016; accepted April 13, 2016; advance publication released online April 23, 2016
}

\begin{abstract}
Chemical investigation of the sponge Dysidea sp. afforded three new sesquiterpene phenols (1-3) and one new sesquiterpene aminoquinone (4), together with four known sesquiterpene derivatives (5-8). The structures of all compounds were unambiguously elucidated by extensive spectroscopic analysis, as well as by comparison with the literature. The absolute configurations of compounds 1-4 were determined by electron capture detector (ECD) calculations and circular dichroism (CD) spectrum analysis. Their antibacterial activity against Escherichia coli (25922), Bacillus subtilis (6633), and Staphylococcus aureus (25923) were evaluated. Compounds 1 and 3 showed weak antibacterial activity against the above three strains, whereas compounds 4-8 showed potent antibacterial activities with minimum inhibitory concentration (MIC) values in the range of 3.125 to $12.5 \mu \mathrm{g} / \mathrm{mL}$.
\end{abstract}

Key words meroterpenoid; marine sponge; antibacterial activity; Dysidea

Marine organisms such as sponges represent a largely unexploited source of a wide variety of natural meroterpenoids. ${ }^{1)}$ Sponges of the genus Dysidea are a rich source of bioactive meroterpenoids, the majority of which are sesquiterpene quinones/quinols. ${ }^{2)}$ This class of compounds frequently consist of sesquiterpene moieties linked to quinones, quinols, or structural analogues. ${ }^{3)}$ The sesquiterpene unit is of biosynthetic interest, as it usually features a drimane- or a 4,9-friedodrimane-type skeleton comprising a trans- or a less common cis-fused ring junction. ${ }^{3)}$ These compounds have attracted much interest due to their structural diversity and varied biological activities, including anti-human immunodeficiency virus (HIV), ${ }^{4)}$ antibacterial, ${ }^{5)}$ antifungal, ${ }^{6)}$ antioxidative, ${ }^{7)}$ antitumor ${ }^{8)}$ anti-inflammatory, ${ }^{9)}$ inhibition against protein tyrosine kinase (PTK) and protein tyrosine phosphatase $1 \mathrm{~B}$ (PTP1B), ${ }^{10,11)}$ and activation of hypoxia-inducible factor-1 (HIF-1) activities. ${ }^{12)}$

During our search for bioactive metabolites from tropical sponges, we encountered a purple-colored encrusting Dysidea sp. off the south China sea. The crude extract of this sponge showed significant antibacterial activity against Staphylococcus aureus (25923) with the minimum inhibitory concentration (MIC) value of $25 \mu \mathrm{g} / \mathrm{mL}$. Chemical investigation of bioactive extracts of this sponge led to the isolation of three new sesquiterpene phenols (1-3) and one new sesquiterpene aminoquinone (4), together with four known sesquiterpene derivatives $(\mathbf{5}-\mathbf{8})$. Herein, we report the details of the purification and structure elucidation of these compounds, as well as the evaluation of antibacterial activity (Fig. 1).

\section{Results and Discussion}

Dysidphenol A (1) was obtained as a colorless oil. The molecular formula $\mathrm{C}_{23} \mathrm{H}_{32} \mathrm{O}_{4}$ was established by high resolutionelectrospray ionization (HR-ESI)-MS, in accordance with the signal observed at $\mathrm{m} / z 373.2382[\mathrm{M}+\mathrm{H}]^{+}$. The UV spectrum, revealing absorbances at $\lambda_{\max } 218$ and $277 \mathrm{~nm}$, suggested the presence of a sesquiterpene phenol chromophore in the molecule. ${ }^{12)}$ The ${ }^{13} \mathrm{C}$-NMR and distortionless enhancement by polarization transfer (DEPT) spectra demonstrated the presence of 23 carbons, accounting for four methyls, one methoxy, six $s p^{3}$ methylenes, two $s p^{3}$ methines, two $s p^{2}$ methines, three $s p^{3}$ quaternary carbons, four $s p^{2}$ quaternary carbons, and one carbonyl carbon. The correlation spectroscopy (COSY) spectrum of 1 suggested the presence of two individual spin systems: $\mathrm{C}-1 / \mathrm{C}-2 / \mathrm{C}-3$ and $\mathrm{C}-5 / \mathrm{C}-6 / \mathrm{C}-7 / \mathrm{C}-8 / \mathrm{C}-13$ as shown in Fig. 2. Heteronuclear multiple bond connectivity (HMBC) correlations from $\mathrm{H}_{3}-11$ to $\mathrm{C}-3, \mathrm{C}-4, \mathrm{C}-5$, and $\mathrm{C}-12$, from $\mathrm{H}_{3}-12$ to $\mathrm{C}-3, \mathrm{C}-4, \mathrm{C}-5$, and $\mathrm{C}-11$, from $\mathrm{H}_{3}-13$ to $\mathrm{C}-7, \mathrm{C}-8$, and $\mathrm{C}-9$, and from $\mathrm{H}_{3}-14$ to $\mathrm{C}-1, \mathrm{C}-5, \mathrm{C}-9$, and $\mathrm{C}-10$ determined the decalin moiety with four methyl groups $\left(\mathrm{CH}_{3}-11, \mathrm{CH}_{3}-12, \mathrm{CH}_{3}-13\right.$, and $\left.\mathrm{CH}_{3}-14\right)$ attached at $\mathrm{C}-4, \mathrm{C}-4, \mathrm{C}-8$, and $\mathrm{C}-10$, respectively. Further HMBC correlation from $\mathrm{H}_{3}-23$ to $\mathrm{C}-22$ positioned the methoxy group at $\mathrm{C}-22$. Moreover, the tetrasubstituted phenyl subunit with a methyl formate group at $\mathrm{C}-18$ was deduced by the HMBC correlations from $\mathrm{H}-17$ to $\mathrm{C}-19, \mathrm{C}-21$, and $\mathrm{C}-22$ and from $\mathrm{H}-19$ to $\mathrm{C}-20, \mathrm{C}-21$, and C-22. Further HMBC correlations of $\mathrm{H}_{2}-15$ with $\mathrm{C}-8, \mathrm{C}-9, \mathrm{C}-10, \mathrm{C}-16, \mathrm{C}-17$, and $\mathrm{C}-21$ suggested that the phenyl group was attached at C-9 via $\mathrm{C}-15$. The quaternary carbon at $\delta_{\mathrm{C}} 100.6$ was indicative of a C-9 oxaspiro center, as in the known compound cyclospongiacatechol, ${ }^{12)}$ which can connect C-9 and C-21 via $O$-atom. Finally, the exchangeable hydroxy proton at $\delta_{\mathrm{H}} 4.84$ was placed at C-20 because of the downfield chemical shift at $\delta_{\mathrm{C}} 138.1$ in the ${ }^{13} \mathrm{C}$-NMR spectrum.

The relative configuration was established by the correlations observed in the nuclear Overhauser effect spectroscopy (NOESY) spectrum of 1 (Fig. 3). The NOESY correlations of $\mathrm{H}_{3}-11 / \mathrm{H}_{3}-14, \mathrm{H}_{3}-14 / \mathrm{H}-8$, and $\mathrm{H}_{3}-14 / \mathrm{H}-3 \mathrm{~b}$ indicated these methyl groups and protons are $\alpha$-oriented, while the correlations of $\mathrm{H}-5 / \mathrm{H}_{3}-12, \mathrm{H}_{3}-13 / \mathrm{H}-15 \mathrm{a}$, and $\mathrm{H}-15 \mathrm{~b} / \mathrm{H}-5$ revealed that these protons are $\beta$-oriented. The absolute configuration of $\mathbf{1}$ was determined as $5 R, 8 S, 9 R$, and $10 R$ by comparison of its 
<smiles>COC(=O)c1cc(O)c2c(c1)C[C@]1(C2)[C@@H](C)CC[C@H]2[C@@H](C)CCC[C@@H]21</smiles>

1<smiles>COC(=O)c1cc(O)c2c(c1)C[C@]1(C)[C@@H](C)CC[C@H]3C(C)(C)CCC[C@]31C2</smiles>

2<smiles>COC(=O)c1ccc(O)c(C[C@H]2[C@@H](C)CC[C@@H]3C(C)(C)CCC[C@@]23C)c1</smiles>

3

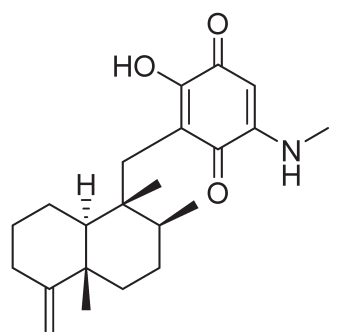

4

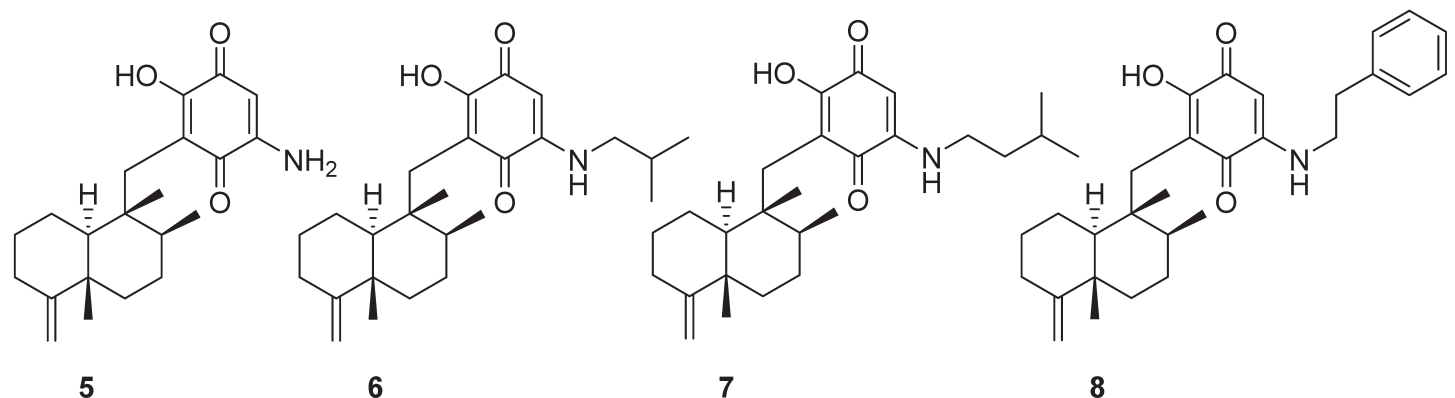

Fig. 1. The Chemical Structures of Compounds 1-8 Isolated from Dysidea sp.

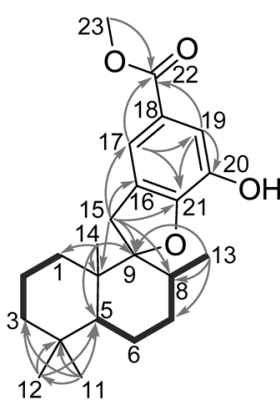

1

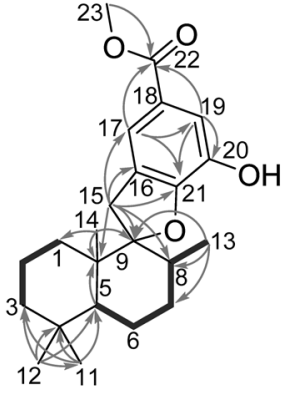

2

$-\cos Y$

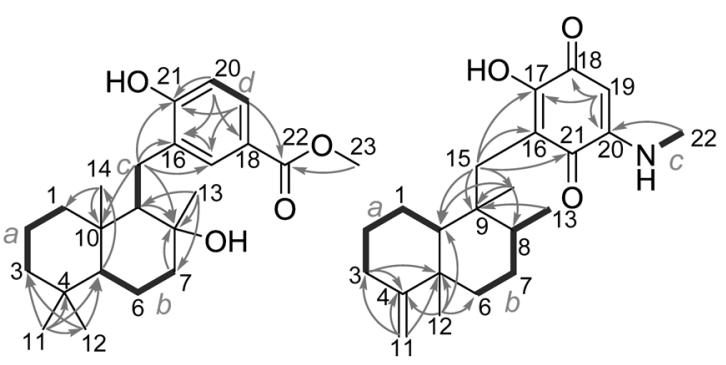

3

Fig. 2. COSY and HMBC Correlations of Compounds 1-4

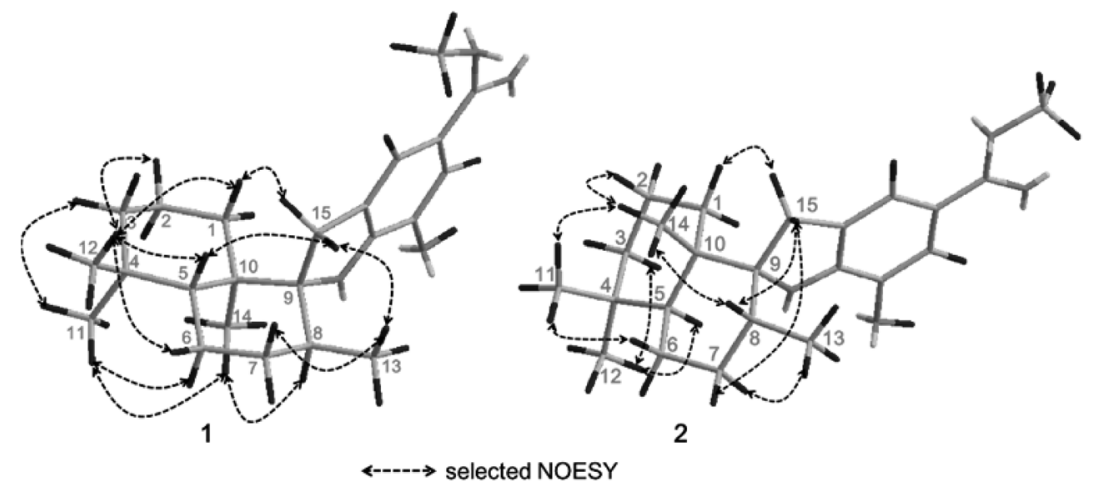

Fig. 3. Selected NOESY Correlations of Compounds $\mathbf{1}$ and $\mathbf{2}$

experimental and calculated electron capture detector (ECD) spectra as shown in Fig. 4.

Dysidphenol B (2) was obtained as a colorless oil, gave the same molecular formula $\mathrm{C}_{23} \mathrm{H}_{32} \mathrm{O}_{4}$ as that of $\mathbf{1}$ by the HR-ESIMS ion at $m / z 373.2381[\mathrm{M}+\mathrm{H}]^{+}$. The ${ }^{1} \mathrm{H}-$ and ${ }^{13} \mathrm{C}-\mathrm{NMR}$ spectroscopic data of $\mathbf{2}$ closely resembled those of $\mathbf{1}$, indicative of the same sesquiterpene phenol core in 2. Further detailed one and two dimensional (1 and 2D)-NMR spectral analysis led to the elucidation of the planar structure of 2 , the same as compound 1 (Fig. 1). However, a comparison with ${ }^{13} \mathrm{C}-\mathrm{NMR}$ data for compound $\mathbf{1}$ showed different chemical shifts of the carbons centered on C-9, including upfield shifts of C-9 


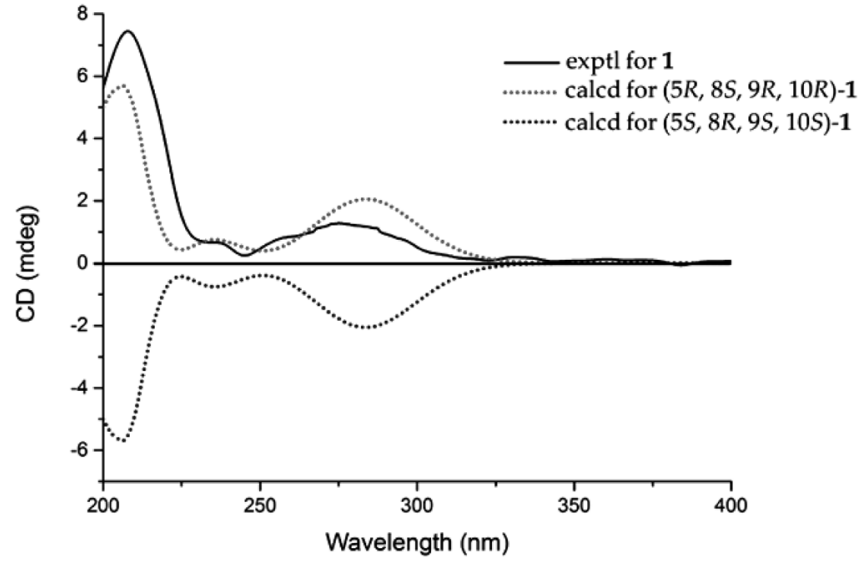

Fig. 4. Experimentally Measured and Calculated ECD Spectra of Dysidphenol A (1)

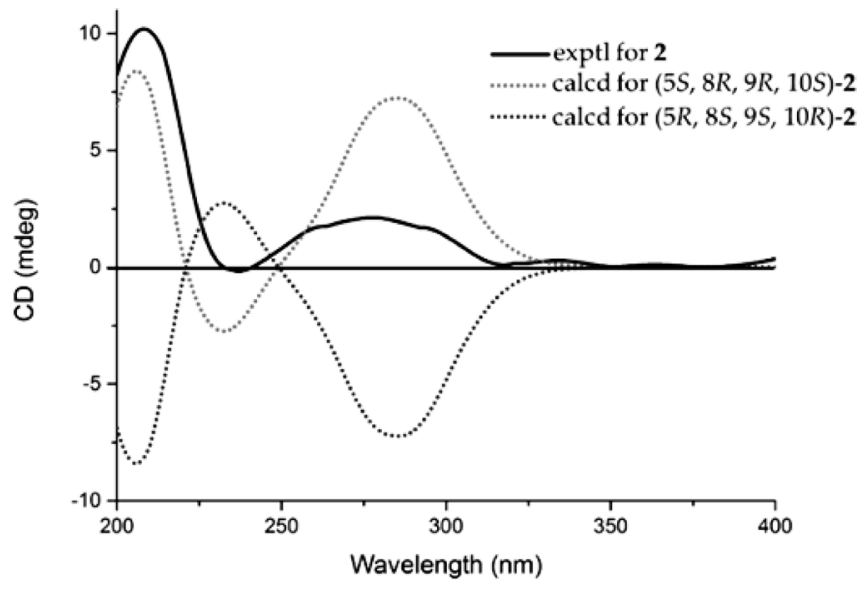

Fig. 5. Experimentally Measured and Calculated ECD Spectra of Dysidphenol B (2)

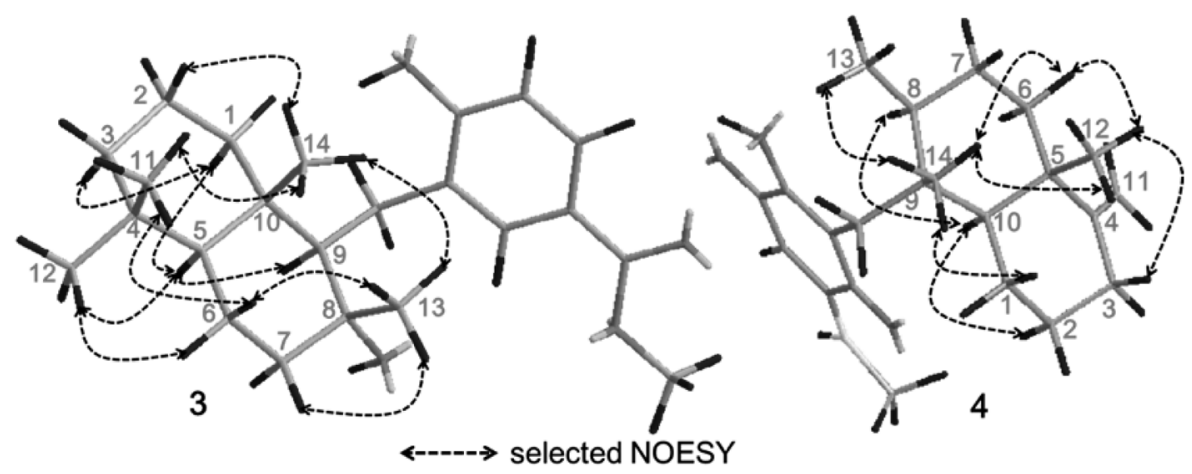

Fig. 6. Selected NOESY Correlations of Compounds 3 and $\mathbf{4}$

(-1.6 ppm), as well as downfield shifts of C-8 (5.5 ppm), C-13 (2.3 ppm), and C-15 (9.6 ppm), which indicated that compounds 1 and $\mathbf{2}$ were a pair of diastereoisomers. Further evidence came from the NOESY correlations of $\mathrm{H}-5 / \mathrm{H}_{3}-12, \mathrm{H}_{3}-11$ / $\mathrm{H}_{3}-14, \mathrm{H}-8 / \mathrm{H}_{3}-14$, and $\mathrm{H}-8 / \mathrm{H}-15 \mathrm{a}$. On the basis of these results, the ether oxygen of compound 2 was determined below the decalin plane. The overall pattern of the circular dichroism (CD) calculated spectrum was in good agreement with the experimental one (Fig. 5). Thus, the absolute configuration of 2 was determined as $5 S, 8 R, 9 R$, and $10 S$.

Dysidphenol C (3) was isolated as colorless oil with the molecular formula $\mathrm{C}_{23} \mathrm{H}_{34} \mathrm{O}_{4}$ by its HR-ESI-MS data $(\mathrm{m} / \mathrm{z}$ $397.2358[\mathrm{M}+\mathrm{Na}]^{+}$), implying seven degrees of unsaturation. The IR spectrum of $\mathbf{3}$ displayed an absorption at $3458 \mathrm{~cm}^{-1}$, suggesting the presence of hydroxy groups. The ${ }^{1} \mathrm{H}-\mathrm{NMR}$ spectrum of $\mathbf{3}$ displayed a characteristic ABX coupling system $\left[\delta_{\mathrm{H}} 7.80(\mathrm{H}-17, \mathrm{~d}, J=1.8 \mathrm{~Hz}), 7.77(\mathrm{H}-19, \mathrm{dd}, J=8.4,1.8 \mathrm{~Hz})\right.$, and $6.82(\mathrm{H}-20, \mathrm{~d}, J=8.4 \mathrm{~Hz})]$ attributed to the presence of 1,3,4-trisubstituted benzene moiety, and signals assignable to four methyl groups $\left[\delta_{\mathrm{H}} 0.82\left(\mathrm{H}_{3}-11, \mathrm{~s}\right), 0.79\left(\mathrm{H}_{3}-12, \mathrm{~s}\right), 1.32\right.$ $\left(\mathrm{H}_{3}-13, \mathrm{~s}\right)$, and $\left.0.95\left(\mathrm{H}_{3}-14, \mathrm{~s}\right)\right]$ attached to quaternary carbons. The ${ }^{13} \mathrm{C}$-NMR spectrum of $\mathbf{3}$ displayed resonances for one carbonyl carbon $\left(\delta_{\mathrm{C}} 167.3\right)$, three olephinic quaternary carbons $\left(\delta_{\mathrm{C}} 120.9,128.7\right.$, and 160.1$)$, three olephinic methines $\left(\delta_{\mathrm{C}} 116.6\right.$, 129.6 , and 133.8), four methyls $\left(\delta_{\mathrm{C}} 15.3,21.4,24.8\right.$, and 33.3$)$, six methylenes $\left(\delta_{\mathrm{C}} 18.2,20.4,27.6,40.2,41.5\right.$, and 43.7), one methine $\left(\delta_{\mathrm{C}} 59.9\right)$, four quaternary carbons $\left(\delta_{\mathrm{C}} 76.5,55.8,40.0\right.$, and 33.1), and one methoxy $\left(\delta_{\mathrm{C}} 51.7\right)$.
Interpretation of the COSY and heteronuclear single quantum coherence (HSQC) spectra of $\mathbf{3}$ led to four isolated spin systems: (a) C1-C2-C3, (b) C5-C6-C7, (c) C9-C15, and (d) C19-C20 (Fig. 2). The connectivity of these four spin systems with the remaining atoms was deduced from the observed HMBC correlations. HMBC correlations from $\mathrm{H}_{3}-11$ to $\mathrm{C}-3$, $\mathrm{C}-4, \mathrm{C}-5$, and $\mathrm{C}-12$, from $\mathrm{H}_{3}-12$ to $\mathrm{C}-3, \mathrm{C}-4, \mathrm{C}-5$, and $\mathrm{C}-11$, from $\mathrm{H}_{3}-13$ to $\mathrm{C}-7, \mathrm{C}-8$, and $\mathrm{C}-9$, from $\mathrm{H}_{3}-14$ to $\mathrm{C}-1, \mathrm{C}-5, \mathrm{C}-9$, and $\mathrm{C}-10$, and from $\mathrm{H}-9$ to $\mathrm{C}-8, \mathrm{C}-10, \mathrm{C}-13$, and $\mathrm{C}-14$ determined the decalin moiety with four methyl groups $\left(\mathrm{H}_{3}-11\right.$, $\mathrm{H}_{3}-12, \mathrm{H}_{3}-13$, and $\mathrm{H}_{3}-14$ ) attached at $\mathrm{C}-4, \mathrm{C}-4, \mathrm{C}-8$, and $\mathrm{C}-10$, respectively. 3-Substituted 4-hydroxybenzoic acid methyl ester moiety was confirmed by the HMBC correlations from $\mathrm{H}-17$ to $\mathrm{C}-16$, from $\mathrm{H}-19$ to $\mathrm{C}-17, \mathrm{C}-21$, and $\mathrm{C}-22$, and from $\mathrm{H}-20$ to $\mathrm{C}-16, \mathrm{C}-18$, and $\mathrm{C}-21$. The HMBC correlations from $\mathrm{H}-15 \mathrm{a}$ and $\mathrm{H}-15 \mathrm{~b}$ to $\mathrm{C}-8, \mathrm{C}-10, \mathrm{C}-16, \mathrm{C}-17$, and $\mathrm{C}-21$ connected decalin moiety and benzene moiety through the methylene group $\mathrm{CH}_{2}-15$, which was confirmed by the HMBC correlations from $\mathrm{H}-9$ and $\mathrm{H}-17$ to $\mathrm{C}-15$. The remaining two hydroxy groups were placed at C-8 and C-21 because of the downfield chemical shifts at $\delta_{\mathrm{C}} 76.5$ and 160.1, respectively. Thus, the planar structure of $\mathbf{3}$ was determined as depicted. In addition, the NOESY correlations of $\mathrm{H}_{3}-11 / \mathrm{H}_{3}-14$ and $\mathrm{H}_{3}-14 / \mathrm{H}_{3}-13$ indicated these methyl groups $\beta$-oriented, while the correlations of $\mathrm{H}_{3}$ $12 / \mathrm{H}-5$ and $\mathrm{H}-5 / \mathrm{H}-9$ revealed that these protons are $\alpha$-oriented (Fig. 6). Finally, the relative configuration of $\mathbf{3}$ was assigned as shown in Fig. 1. Comparion of the experimental and calculated ECD spectra of $\mathbf{3}$ determined its absolute configuration 
as $5 S, 8 R, 9 R$, and $10 S$ (Fig. 7).

Smenospongimine (4) was isolated as purple-red powders. The HR-ESI-MS showed a quasimolecular ion at $\mathrm{m} / z 356.2224$ $[\mathrm{M}-\mathrm{H}]^{-}$, consistent with a molecular formula of $\mathrm{C}_{22} \mathrm{H}_{31} \mathrm{NO}_{3}$. The IR absorption at $1593 \mathrm{~cm}^{-1}$ and $3340 \mathrm{~cm}^{-1}$ and the UV

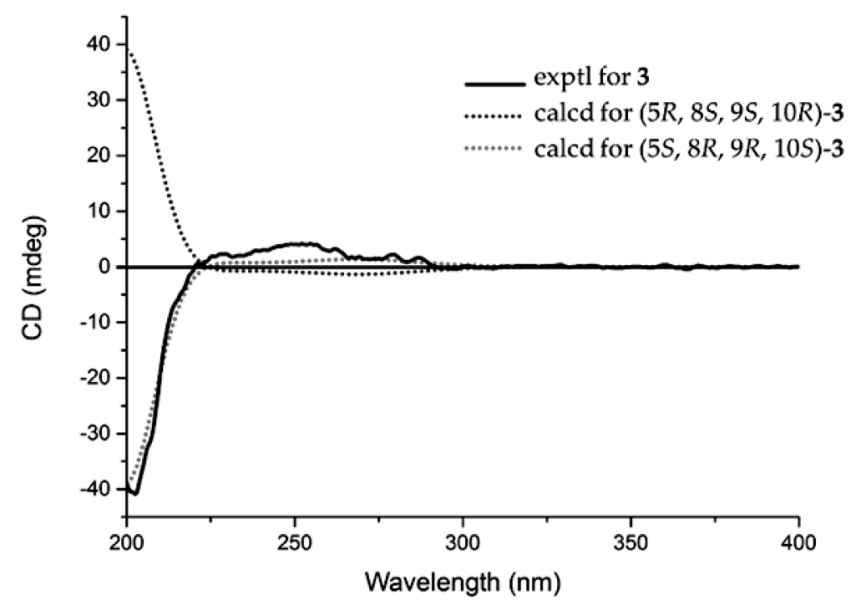

Fig. 7. Experimentally Measured and Calculated ECD Spectra of Dysidphenol C (3) characteristic absorptions at 208 and $313 \mathrm{~nm}$ indicated the presence of a sesquiterpene aminoquinone group. ${ }^{13,14)}$ The ${ }^{1} \mathrm{H}-\mathrm{NMR}$ spectrum of $\mathbf{4}$ displayed signals for two methyl singlets at $\delta_{\mathrm{H}} 1.07$ and $0.94\left(\mathrm{H}_{3}-12\right.$ and $\mathrm{H}_{3}-14$, respectively), a methyl doublet at $\delta_{\mathrm{H}} 1.24\left(\mathrm{H}_{3}-13\right)$ and a pair of exocyclic methylene signals at $\delta_{\mathrm{H}} 4.46$ and $4.47\left(\mathrm{H}_{2}-11\right)$. These signals are characteristic resonances found in most of the rearranged drimane skeleton. ${ }^{15)}$ The ${ }^{1} \mathrm{H}$ - and ${ }^{13} \mathrm{C}$-NMR spectra (Table 1 ) suggested the presence of a dioxygenated-1,4-benzoquinone moiety $\left[\delta_{\mathrm{H}} 5.48(1 \mathrm{H}, \mathrm{s}) ; \delta_{\mathrm{C}} 93.2(\mathrm{CH}), 114.9(\mathrm{C}), 152.1(\mathrm{C})\right.$, $161.6(\mathrm{C}), 179.8(\mathrm{C}), 184.1(\mathrm{C})]^{3)}$

Interpretation of the COSY and HSQC spectra of $\mathbf{4}$ led to the assignment of three isolated spin systems: (a) $\mathrm{C} 10-\mathrm{C} 1-$ $\mathrm{C} 2-\mathrm{C} 3$, (b) $\mathrm{C} 6-\mathrm{C} 7-\mathrm{C} 8-\mathrm{C} 13$, and (c) $\mathrm{NH}-\mathrm{C} 22$, as shown in Fig. 2. HMBC correlations from $\mathrm{H}_{2}-11$ to $\mathrm{C}-3, \mathrm{C}-4$, and $\mathrm{C}-5$, from $\mathrm{H}_{3}-12$ to $\mathrm{C}-4, \mathrm{C}-5, \mathrm{C}-6$, and $\mathrm{C}-10$, from $\mathrm{H}_{3}-13$ to $\mathrm{C}-7$, $\mathrm{C}-8$, and $\mathrm{C}-9$, and from $\mathrm{H}_{3}-14$ to $\mathrm{C}-8, \mathrm{C}-9$, and $\mathrm{C}-10$, determined the rearranged drimane moiety with one exomethylene $\left(\mathrm{H}_{2}-11\right)$ attached at $\mathrm{C}-4$, and three methyl groups $\left(\mathrm{H}_{3}-12\right.$, $\mathrm{H}_{3}-13$, and $\mathrm{H}_{3}-14$ ) attached at $\mathrm{C}-5, \mathrm{C}-8$, and $\mathrm{C}-9$, respectively (Fig. 2). Further HMBC correlations of $\mathrm{H}_{2}-15$ to C-8, C-9, $\mathrm{C}-10, \mathrm{C}-16, \mathrm{C}-17$, and $\mathrm{C}-21$ and of $\mathrm{H}-19$ to $\mathrm{C}-17, \mathrm{C}-18$, and $\mathrm{C}-20$ and the downfield-shifted signal of $\mathrm{C}-17\left(\delta_{\mathrm{C}} 161.6\right)$ estab-

Table 1. ${ }^{1} \mathrm{H}-(600 \mathrm{MHz})$ and ${ }^{13} \mathrm{C}-(150 \mathrm{MHz})$ NMR Spectroscopic Data of $\mathbf{1}-\mathbf{4}$

\begin{tabular}{|c|c|c|c|c|c|c|c|c|}
\hline \multirow{2}{*}{ No. } & \multicolumn{2}{|r|}{$\mathbf{1}^{a)}$} & \multicolumn{2}{|r|}{$2^{a)}$} & \multicolumn{2}{|r|}{$3^{a)}$} & \multicolumn{2}{|r|}{$4^{b)}$} \\
\hline & $\delta_{\mathrm{C}}$ & $\delta_{\mathrm{H}}$, mult. $(J$ in $\mathrm{Hz})$ & $\delta_{\mathrm{C}}$ & $\delta_{\mathrm{H}}$, mult. $(J$ in $\mathrm{Hz})$ & $\delta_{\mathrm{C}}$ & $\delta_{\mathrm{H}}$, mult. $(J$ in $\mathrm{Hz})$ & $\delta_{\mathrm{C}}$ & $\delta_{\mathrm{H}}$, mult. $(J$ in $\mathrm{Hz})$ \\
\hline $1 \alpha$ & $30.6, \mathrm{CH}_{2}$ & $1.30, \mathrm{~m}$ & $31.7, \mathrm{CH}_{2}$ & $1.25, \mathrm{~m}$ & $40.2, \mathrm{CH}_{2}$ & $0.62, \operatorname{td}(13.2,3.6)$ & $24.0, \mathrm{CH}_{2}$ & $2.51, \mathrm{~m}$ \\
\hline $1 \beta$ & & $1.14, \mathrm{~m}$ & & $1.14, \mathrm{~m}$ & & $1.73, \mathrm{t}(13.2)$ & & $1.49, \mathrm{~m}$ \\
\hline $2 \alpha$ & 17.6, $\mathrm{CH}_{2}$ & $1.36, \mathrm{~m}$ & $16.5, \mathrm{CH}_{3}$ & $1.34, \mathrm{~m}$ & $18.2, \mathrm{CH}_{2}$ & $1.36, \mathrm{~m}$ & $29.3, \mathrm{CH}_{2}$ & $1.48, \mathrm{~m}$ \\
\hline $2 \beta$ & & $1.59, \mathrm{~m}$ & & $1.60, \mathrm{~m}$ & & $1.54, \mathrm{~m}$ & & $1.86, \mathrm{~m}$ \\
\hline $3 \alpha$ & $41.4, \mathrm{CH}_{2}$ & $1.40, \mathrm{~m}$ & $41.4, \mathrm{CH}_{2}$ & $1.13, \mathrm{~m}$ & $41.5, \mathrm{CH}_{2}$ & $1.01, \mathrm{~m}$ & $30.7, \mathrm{CH}_{2}$ & $2.04, \mathrm{~m}$ \\
\hline $3 \beta$ & & $1.20, \mathrm{~m}$ & & $1.40, \mathrm{~m}$ & & $1.27, \mathrm{~m}$ & & $2.35, \mathrm{dd}(13.2,5.4)$ \\
\hline 4 & $32.5, \mathrm{C}$ & & $32.5, \mathrm{C}$ & & $33.1, \mathrm{C}$ & & 160.6, C & \\
\hline 5 & $47.6, \mathrm{CH}$ & $1.05, \mathrm{~m}$ & $48.7, \mathrm{CH}$ & $1.07, \mathrm{~m}$ & $55.8, \mathrm{C}$ & 0.93 , dd $(12.6,2.4)$ & $41.1, \mathrm{C}$ & \\
\hline $6 \alpha$ & 20.6, $\mathrm{CH}_{2}$ & $1.44, \mathrm{~m}$ & 17.2, $\mathrm{CH}_{2}$ & $1.48, \mathrm{~m}$ & $20.4, \mathrm{CH}_{2}$ & $1.30, \mathrm{~m}$ & $37.5, \mathrm{CH}_{2}$ & $1.39, \mathrm{~m}$ \\
\hline $6 \beta$ & & $1.55, \mathrm{~m}$ & & $1.54, \mathrm{~m}$ & & $1.68, \mathrm{~m}$ & & $1.50, \mathrm{~m}$ \\
\hline $7 \alpha$ & $30.4, \mathrm{CH}_{2}$ & $1.08, \mathrm{~m}$ & $29.0, \mathrm{CH}_{2}$ & $1.26, \mathrm{~m}$ & $43.7, \mathrm{CH}_{2}$ & $1.63, \mathrm{~m}$ & 28.7, $\mathrm{CH}_{2}$ & $1.42, \mathrm{~m}$ \\
\hline $7 \beta$ & & $1.71, \mathrm{~m}$ & & $1.66, \mathrm{~m}$ & & $1.89, \mathrm{dt}(12.6,3.0)$ & & \\
\hline 8 & $34.7, \mathrm{CH}$ & $2.30, \mathrm{~m}$ & $40.2, \mathrm{CH}$ & $2.11, \mathrm{~m}$ & $76.5, \mathrm{C}$ & & $38.5, \mathrm{CH}$ & $1.56, \mathrm{~m}$ \\
\hline 9 & $100.6, \mathrm{C}$ & & $99.0, \mathrm{CH}$ & & $59.9, \mathrm{CH}$ & $1.65, \mathrm{~m}$ & $43.4, \mathrm{C}$ & \\
\hline 10 & $42.9, \mathrm{C}$ & & $42.9, \mathrm{C}$ & & $40.0, \mathrm{C}$ & & $50.6, \mathrm{CH}$ & 1.16 , dd $(10.8,1.8)$ \\
\hline $11 \mathrm{a}$ & 21.1, $\mathrm{CH}_{3}$ & $0.88, \mathrm{~s}$ & 21.0, $\mathrm{CH}_{3}$ & $0.89, \mathrm{~s}$ & $33.3, \mathrm{CH}_{3}$ & $0.82, \mathrm{~s}$ & $103.5, \mathrm{CH}_{2}$ & $4.46, \mathrm{~s}$ \\
\hline $11 \mathrm{~b}$ & & & & & & & & $4.47, \mathrm{~s}$ \\
\hline 12 & $32.9, \mathrm{CH}_{3}$ & $0.90, \mathrm{~s}$ & $33.0, \mathrm{CH}_{3}$ & $0.92, \mathrm{~s}$ & $21.4, \mathrm{CH}_{3}$ & $0.79, \mathrm{~s}$ & $21.0, \mathrm{CH}_{3}$ & $1.07, \mathrm{~s}$ \\
\hline 13 & $14.3, \mathrm{CH}_{3}$ & $0.75, \mathrm{~d}(6.6)$ & $16.6, \mathrm{CH}_{3}$ & $1.22, \mathrm{~d}(7.2)$ & $24.8, \mathrm{CH}_{3}$ & $1.32, \mathrm{~s}$ & $19.0, \mathrm{CH}_{3}$ & $1.24, \mathrm{~d}(6.6)$ \\
\hline 14 & $14.8, \mathrm{CH}_{3}$ & $1.20, \mathrm{~s}$ & $16.5, \mathrm{CH}_{3}$ & $1.21, \mathrm{~s}$ & $15.3, \mathrm{CH}_{3}$ & $0.95, \mathrm{~s}$ & $18.2, \mathrm{CH}_{3}$ & $0.94, \mathrm{~s}$ \\
\hline $15 \mathrm{a}$ & $30.4, \mathrm{CH}_{2}$ & $3.06, \mathrm{~d}(16.8)$ & $40.0, \mathrm{CH}_{2}$ & $2.93, \mathrm{~d}(16.2)$ & 27.6, $\mathrm{CH}_{2}$ & $2.52, \mathrm{dd}(15.0,6.6)$ & $30.2, \mathrm{CH}_{2}$ & 2.71, d (13.2) \\
\hline $15 b$ & & $3.25, \mathrm{~d}(16.8)$ & & $3.64, \mathrm{~d}(16.2)$ & & $2.90, \mathrm{~d}(15.0)$ & & $2.80, \mathrm{~d}(13.2)$ \\
\hline 16 & $127.8, \mathrm{C}$ & & $127.4, \mathrm{C}$ & & $128.7, \mathrm{C}$ & & $114.9, \mathrm{C}$ & \\
\hline 17 & $118.1, \mathrm{CH}$ & 7.46, d (1.8) & $118.3, \mathrm{CH}$ & $7.44, \mathrm{~d}(1.8)$ & $133.8, \mathrm{CH}$ & $7.80, \mathrm{~d}(1.8)$ & 161.6, C & \\
\hline 18 & $122.1, \mathrm{C}$ & & $122.2, \mathrm{C}$ & & $120.9, \mathrm{C}$ & & 184.1, C & \\
\hline 19 & $115.9, \mathrm{CH}$ & 7.44, d (1.8) & $115.8, \mathrm{CH}$ & 7.46, d (1.8) & $129.6, \mathrm{CH}$ & $7.77, \mathrm{dd}(8.4,1.8)$ & $93.2, \mathrm{CH}$ & $5.48, \mathrm{~s}$ \\
\hline 20 & $138.1, \mathrm{C}$ & & $138.7, \mathrm{C}$ & & $116.6, \mathrm{CH}$ & $6.82, \mathrm{~d}(8.4)$ & $152.1, \mathrm{C}$ & \\
\hline $20-\mathrm{OH}$ & & 4.84 , brs & & 4.87, brs & & & & \\
\hline 21 & $150.9, \mathrm{C}$ & & $150.3, \mathrm{C}$ & & $160.1, \mathrm{C}$ & & $179.8, \mathrm{C}$ & \\
\hline 22 & $166.6, \mathrm{C}$ & & $166.5, \mathrm{C}$ & & $167.3, \mathrm{C}$ & & $29.5, \mathrm{CH}_{3}$ & $2.68, \mathrm{~d}(5.4)$ \\
\hline 23 & $51.3,-\mathrm{OCH}_{3}$ & $3.87, \mathrm{~s}$ & $51.3,-\mathrm{OCH}_{3}$ & $3.87, \mathrm{~s}$ & $51.7,-\mathrm{OCH}_{3}$ & $3.86, \mathrm{~s}$ & & \\
\hline $21-\mathrm{NH}$ & & & & & & & & $8.36, \mathrm{q}(4.8)$ \\
\hline
\end{tabular}

a) Measured in $\mathrm{CDCl}_{3}$.b) Measured in pyridine- $d_{5}$. 


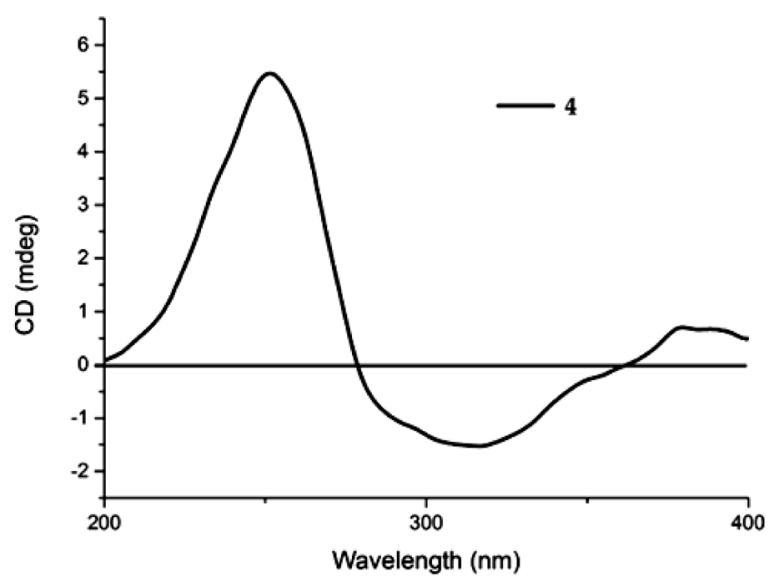

Fig. 8. Experimental CD Spectrum of Smenospongimine (4)

Table 2. Evaluation of the Antibacterial Activities for Compounds $\mathbf{1 - 8}$

\begin{tabular}{cccc}
\hline \hline Compounds & B. subtilis & S. aureus & E. coli \\
\hline $\mathbf{1}$ & 100.0 & 100.0 & 100.0 \\
$\mathbf{2}$ & $\mathrm{NA}$ & $\mathrm{NA}$ & $\mathrm{NA}$ \\
$\mathbf{3}$ & 50.0 & 50.0 & 50.0 \\
$\mathbf{4}$ & 3.125 & 3.125 & 6.25 \\
$\mathbf{5}$ & 3.125 & 3.125 & 3.125 \\
$\mathbf{6}$ & 3.125 & 3.125 & 12.5 \\
$\mathbf{7}$ & 6.25 & 6.25 & 12.5 \\
$\mathbf{8}$ & 3.125 & 3.125 & 6.25 \\
Chloromycetin & 3.125 & 3.125 & 3.125 \\
\hline
\end{tabular}

$\mathrm{NA}=$ Not active. $\mathrm{MIC}(\mu \mathrm{g} / \mathrm{mL}),(n=3)$

lished the 17-hydroxyquinone subunit and its connection to the sesquiterpenoid moiety at $\mathrm{C}-16$ via $\mathrm{C}-15$. Taken together with HMBC correlation from $\mathrm{H}_{3}-22$ to $\mathrm{C}-20$ and the chemical shift of $\mathrm{C}-20\left(\delta_{\mathrm{C}} 152.1\right)$ suggested that the methylamino fragment was unambiguously determined to be tethered to C-20. Thus, the planar structure of $\mathbf{4}$ was finally determined.

The relative configuration was established on the basis of NOESY correlations (Fig. 6). Key NOESY correlations of $\mathrm{H}_{3}-12$ with $\mathrm{H}_{3}-14$ and $\mathrm{H}-10$ with $\mathrm{H}-8$ indicated their cofacial orientation, respectively. According to the literature, ${ }^{13} \mathrm{C}-\mathrm{NMR}$ chemical shift values of $\mathrm{C}-12$ in trans-decalins are more shielded than those in cis-decalins $(\Delta c a .10 \mathrm{ppm}){ }^{3)}$ The shielded ${ }^{13} \mathrm{C}-\mathrm{NMR}$ chemical shift value of C-12 $\left(\delta_{\mathrm{C}} 21.0\right)$ confirmed a trans rather than cis junction of the decalin ring. Thus, the relative configuration of $\mathbf{4}$ was finally assigned as shown in Fig. 1. In the CD spectrum of $\mathbf{4}$, the positive Cotton effect at $254 \mathrm{~nm}$ and negative Cotton effect at $315 \mathrm{~nm}$ as shown in Fig. 8, supported that the absolute configuration for 4 was $5 S, 8 S, 9 R$, and $10 S .^{13)}$

In addition to four new compounds $\mathbf{1 - 4}$, four known compounds, identified as smenospongine (5), smenospongorine (6), smenospongiarine (7), and smenospongidine (8) were also isolated from Dysidea sp. ${ }^{16)}$ These compounds were identified by spectral analysis, and we found their spectral data were consistent with spectroscopic data reported in the corresponding literature.

All the isolated compounds were evaluated for antibacterial activity against Escherichia coli (25922), Bacillus subtilis (6633), and Staphylococcus aureus (25923) (Table 2). Com- pounds $\mathbf{1}$ and $\mathbf{3}$ showed weak antibacterial activity against the above three strains. However, compounds 4-8 showed potent antibacterial activities with MIC values in the range of 3.125 to $12.5 \mu \mathrm{g} / \mathrm{mL}$. In terms of the sensitivities of the different strains to compounds $\mathbf{4 - 8}, B$. subtilis and $S$. aureus were found to be the most sensitive, followed by E. coli. These results showed that the presence of the aminoquinones units can positively affected the activity.

\section{Experimental}

General Experimental Procedures Optical rotations were obtained on a Perkin-Elmer 341 digital polarimeter (Waltham, MA, U.S.A.) with a $10 \mathrm{~cm}$ length cell at room temperature (r.t.). UV and IR ( $\mathrm{KBr}$ ) spectra were recorded on Hitachi U-3010 spectrophotometer (Hitachi, Inc., Tokyo, Japan) and Thermo Nicolet Nexus 870 FT-IR E.S.P. spectrometer (Beijing, China), respectively. CD spectra were measured with a Chirascan circular dichroism spectrometer (Applied Photophysics, Surrey, U.K.). NMR data were acquired on a Bruker Avance DRX-600 MHz NMR spectrometer (Bruker Biospin Corp., Billerica, MA, U.S.A.). HR-ESI-MS and ESI-MS data were obtained on a Waters Q-Tof micro YA019 mass spectrometer (Waters Corp., Milford, MA, U.S.A.). A Shimadzu LC-20 AT (Shimadzu Corporation, Kyoto, Japan) equipped with an SPD-M20A PDA detector (Shimadzu Corporation) was used for HPLC, a YMC-pack ODS-A column $(250 \times 10 \mathrm{~mm}$, $5 \mu \mathrm{m}, 12 \mathrm{~nm}$ ) was used for semipreparative HPLC separation. Silica gel (200-300 mesh; Qingdao Marine Chemical Factory, China), ODS $(50 \mu \mathrm{m}$, YMC Co., Ltd., Kyoto, Japan), and Sephadex LH-20 (GE Healthcare Life Sciences, Shanghai, China) were used for column chromatography (CC). TLC analysis was performed using on Silica gel GF254 plates (10-40 $\mu \mathrm{m}$; Qingdao Marine Chemical Factory, Qingdao, China). Spots were detected on TLC under UV light or by heating after spraying with anisaldehyde- $\mathrm{H}_{2} \mathrm{SO}_{4}$ reagent.

Animal Material Samples of Dysidea sp. were collected from the coral-reef regions near YongXing Island $\left(16^{\circ} 50^{\prime} \mathrm{N}\right.$, $\left.112^{\circ} 20^{\prime} \mathrm{E}\right)$ in the South China Sea, in June 2013, at a depth of about $20 \mathrm{~m}$, and frozen immediately after collection. The sponge was identified by Professor Yue-Wei Guo (Shanghai Institute of Materia Medica, Chinese Academy of Sciences). A voucher specimen (No. YX1305) is deposited in the Department of Pharmacy, Shandong University of Traditional Chinese Medicine, People's Republic of China.

Extraction and Isolation The air-dried sponge $(0.3 \mathrm{~kg}$, dry weight) was powdered and extracted with $95 \%$ aqueous EtOH at r.t. The combined extracts were concentrated under reduced pressure to yield the crude extract $(22.0 \mathrm{~g})$, which was suspended in $\mathrm{H}_{2} \mathrm{O}$ and extracted sequentially with $\mathrm{CH}_{2} \mathrm{Cl}_{2}$ and $n$ - $\mathrm{BuOH}$ to afford $\mathrm{CH}_{2} \mathrm{Cl}_{2}$-soluble extract (10.4 g) and $n$-BuOH-soluble extract $(10.0 \mathrm{~g})$. The $\mathrm{CH}_{2} \mathrm{Cl}_{2}$-soluble extract was subjected to vacuum liquid chromatography on silica gel by gradient elution using $n$-hexane-acetone $(80: 1,60: 1$, $50: 1,30: 1,20: 1,10: 1,8: 1,5: 1,1: 1,0: 1, \mathrm{v} / \mathrm{v})$ as solvents to give seven fractions $(\mathrm{A}-\mathrm{G})$. Fraction $\mathrm{B}(1.8 \mathrm{~g})$ was subjected to $\mathrm{CC}$ on Sephadex LH-20 with $\mathrm{CH}_{2} \mathrm{Cl}_{2}-\mathrm{MeOH}(1: 1)$ as the eluting solvent to afford eight subfractions (B1-B8). Fraction B5 was separated by reversed-phase HPLC eluting with $92 \%$ MeCN detected at $315 \mathrm{~nm}$ to afford compound $\mathbf{5}$ $\left(2.0 \mathrm{~mL} / \mathrm{min}, t_{\mathrm{R}}=32.0 \mathrm{~min}, 8.9 \mathrm{mg}\right)$ and compound $6(2.0 \mathrm{~mL} /$ min, $t_{\mathrm{R}}=34.3 \mathrm{~min}, 4.5 \mathrm{mg}$ ). Fraction $\mathrm{B} 5$ was purified by 
reversed-phase HPLC with an elution of $30 \% \mathrm{MeCN}$ detected at the wavelength of $315 \mathrm{~nm}$ to give compound $7(2.0 \mathrm{~mL} / \mathrm{min}$, $\left.t_{\mathrm{R}}=37.0 \mathrm{~min}, 2.9 \mathrm{mg}\right)$. Fraction $\mathrm{C}(2.6 \mathrm{~g})$ was further separated on an octadecyl silica (ODS) $(50 \mu \mathrm{m})$ column followed by stepwise gradient elution with $\mathrm{MeOH} / \mathrm{H}_{2} \mathrm{O}(3: 2,4: 1,1: 0)$ to afford ten fractions $(\mathrm{C} 1-\mathrm{C} 10)$, and then fraction $\mathrm{C} 8$ was purified by reversed-phase HPLC with an elution of $92 \% \mathrm{MeCN}$ to give compound $8\left(2.0 \mathrm{~mL} / \mathrm{min}, t_{\mathrm{R}}=41.0 \mathrm{~min}, 10.9 \mathrm{mg}\right)$. Fraction D $(2.1 \mathrm{~g})$ was separated by $\mathrm{CC}$ on ODS $(50 \mu \mathrm{m})$ eluting with $\mathrm{MeOH}-\mathrm{H}_{2} \mathrm{O}(3: 2-1: 0)$ to give ten fractions (Frs. D1D10). Fraction D7 was subjected to column chromatography (CC) on Sephadex LH-20 with $\mathrm{CH}_{2} \mathrm{Cl}_{2}-\mathrm{MeOH}(1: 1)$ as the eluting solvent to afford six subfractions (D71-D76). Subfraction D74 was purified by reversed-phase HPLC, eluting with $90 \% \mathrm{MeCN}$ detected at $264 \mathrm{~nm}$, to give $1(2.0 \mathrm{~mL} / \mathrm{min}$, $\left.t_{\mathrm{R}}=43.3 \mathrm{~min}, 1.8 \mathrm{mg}\right)$ and $2\left(2.0 \mathrm{~mL} / \mathrm{min}, t_{\mathrm{R}}=53.2 \mathrm{~min}, 1.9 \mathrm{mg}\right)$, whereas the purification of D75 by reversed-phase HPLC eluting with $85 \% \mathrm{MeCN}$ resulted in the isolation of $3(2.0 \mathrm{~mL} /$ $\left.\min , 250 \mathrm{~nm}, t_{\mathrm{R}}=25.0 \mathrm{~min}, 3.3 \mathrm{mg}\right)$ and $4(2.0 \mathrm{~mL} / \mathrm{min}, 315 \mathrm{~nm}$, $\left.t_{\mathrm{R}}=36.3 \mathrm{~min}, 5.2 \mathrm{mg}\right)$.

Dysidphenol A (1)

Colorless oil; $[\alpha]_{\mathrm{D}}^{25}+5.2(c 0.16, \mathrm{MeOH})$; UV (MeOH) $(\log \varepsilon)$ $\lambda_{\text {max }} 218$ (4.23), 277 (3.05); $\mathrm{CD}\left(2.7 \times 10^{-4} \mathrm{M}, \mathrm{MeCN}\right), \lambda_{\max }(\Delta \varepsilon)$ $208(+8.38), 235(+0.84)$, and $278(+1.27) \mathrm{nm}$; IR $(\mathrm{KBr}) v_{\max }$ 3366, 2956, 2927, 2856, 1714, 1608, 1460, 1440, 1349, 1221, 1063, 944, 804, 770, 657, $604 \mathrm{~cm}^{-1} ;{ }^{1} \mathrm{H}-$ and ${ }^{13} \mathrm{C}-\mathrm{NMR}$ data, see Table 1; HR-ESI-MS $\mathrm{m} / z$ 373.2382 $[\mathrm{M}+\mathrm{H}]^{+}$(Calcd for $\mathrm{C}_{23} \mathrm{H}_{33} \mathrm{O}_{4}, 373.2379$ ).

Dysidphenol B (2)

Colorless oil; $[\alpha]_{\mathrm{D}}^{25}-3.1(c 0.17, \mathrm{MeOH}) ; \mathrm{UV}(\mathrm{MeOH})(\log \varepsilon)$ $\lambda_{\text {max }} 218$ (4.72), 280 (4.08); CD $\left(5.4 \times 10^{-4} \mathrm{M}, \mathrm{MeCN}\right), \lambda_{\max }(\Delta \varepsilon)$ $208(+5.75), 236(-0.09)$, and $278(+1.19) \mathrm{nm}$; IR $(\mathrm{KBr}) v_{\max }$ 3366, 2926, 2856, 1714, 1693, 1608, 1439, 1350, 1261, 1228, 1089, 1058, 801, $733 \mathrm{~cm}^{-1}$; ${ }^{1} \mathrm{H}$ - and ${ }^{13} \mathrm{C}-\mathrm{NMR}$ data, see Table 1; HR-ESI-MS $\mathrm{m} / \mathrm{z} 373.2381[\mathrm{M}+\mathrm{H}]^{+}$(Calcd for $\mathrm{C}_{23} \mathrm{H}_{33} \mathrm{O}_{4}$, 373.2379).

Dysidphenol C (3)

Colorless oil; $[\alpha]_{\mathrm{D}}^{25}-46.1$ (c $\left.0.14, \mathrm{MeOH}\right) ; \mathrm{UV}(\mathrm{MeOH})$ $(\log \varepsilon) \lambda_{\max } 218$ (2.86), 262 (2.71); CD $\left(2.7 \times 10^{-4} \mathrm{M}, \mathrm{MeCN}\right)$, $\lambda_{\text {max }}(\Delta \varepsilon) 202(-45.4) \mathrm{nm}$; IR (KBr) $v_{\max } 3458,2927,2853$, $1716,1692,1610,1582,1449,1441,1386,1295,1237,1112$, 1086, 802, $770 \mathrm{~cm}^{-1}$; ${ }^{1} \mathrm{H}-$ and ${ }^{13} \mathrm{C}-\mathrm{NMR}$ data, see Table 1; HR-ESI-MS m/z $397.2358[\mathrm{M}+\mathrm{Na}]^{+}$(Calcd for $\mathrm{C}_{23} \mathrm{H}_{34} \mathrm{O}_{4} \mathrm{Na}$, 397.2355).

Smenospongimine (4)

Purple-red powders; UV (MeOH) (log $\varepsilon) \lambda_{\max } 227$ (4.47), 292 (4.28); $\mathrm{CD}\left(2.8 \times 10^{-4} \mathrm{M}, \mathrm{MeCN}\right), \lambda_{\max }(\Delta \varepsilon) 254(+5.92)$ and $315(-2.31) \mathrm{nm}$; IR (KBr) $v_{\max } 3340,2956,2926,2856$, $1737,1651,1593,1512,1460,1390,1226,1080,801 \mathrm{~cm}^{-1} ;{ }^{1} \mathrm{H}-$ and ${ }^{13} \mathrm{C}$-NMR data, see Table 1; HR-ESI-MS $\mathrm{m} / \mathrm{z} 356.2224$ $[\mathrm{M}-\mathrm{H}]^{-}$(Calcd for $\mathrm{C}_{22} \mathrm{H}_{30} \mathrm{NO}_{3}, 356.2226$ ).

Energy Minimization and ECD Calculations The initial conformations of $\mathbf{1}, \mathbf{2}$, and $\mathbf{3}$ were optimized using the MMFF94 method in MarvinSketch 5.8.1 and then the HF/6-31G(d) method in Gaussian 09. ${ }^{17)}$ Further optimization at the B3P86/6-31G(d) level led to the final dihedral angles. The optimized conformations were used for the ECD calculations, which were performed with Gaussian 09 (B3P86/6-311++G $(2 \mathrm{~d}, \mathrm{p})$ ). The solvent effects were taken into account by the conductor-like polarizable calculation model (CPCM, MeCN as the solvent).
Biological Assays The antimicrobial activities against $E$. coli, B. subtilis, and $S$. aureus were evaluated by the broth dilution method. ${ }^{18,19)}$ Briefly, The tested strains were cultivated in mueller-hinton broth medium for bacteria at $37^{\circ} \mathrm{C}$. Chloromycetin was used as a positive control. Compounds and positive control were dissolved in dimethyl sulfoxide (DMSO) at different concentrations from 100 to $0.01 \mu \mathrm{g} / \mathrm{mL}$ by the continuous 2-fold dilution method. A $100 \mu \mathrm{L}$ quantity of test solution were added in each well of the 96-well plates (Corning). Each well was then inoculated with a standard inoculum $(100 \mu \mathrm{L})$ of an overnight culture of bacteria adjusted so that each test received $3 \times 10^{5}-5 \times 10^{5} \mathrm{CFU}$ (colony-forming units)/ $\mathrm{mL}$. MICs were defined as the lowest concentration at which no microbial growth could be observed.

\section{Conclusion}

In summary, three new sesquiterpene phenols (1-3) and one new sesquiterpene aminoquinone (4), together with four known sesquiterpene derivatives $(\mathbf{5}-\mathbf{8})$, were isolated from the South China Sea sponge Dysidea sp. The new structures were determined by extensive spectroscopic analyses, and their absolute configurations were assigned by ECD calculations and CD spectrum analysis. The antibacterial results of compounds 1-8 indicated that the presence of the aminoquinones units might have contributed to the inhibition of the growth of $E$. coli (25922), B. subtilis (6633), and S. aureus (25923).

Acknowledgment This research was supported by the National Natural Science Foundation of China (No. 81402833).

Conflict of Interest The authors declare no conflict of interest.

Supplementary Materials The online version of this article contains supplementary materials.

\section{References}

1) Blunt J. W., Copp B. R., Keyzers R. A., Munro M., Prinsep M. R., Nat. Prod. Rep., 32, 116-211 (2015).

2) Jiao W.-H., Xu T.-T., Yu H.-B., Chen G.-D., Huang X.-J., Yang F., Li Y.-S., Han B.-N., Liu X.-Y., Lin H.-W., J. Nat. Prod., 77, 346-350 (2014).

3) Daletos G., de Voogd N. J., Müller W. E. G., Wray V., Lin W. H., Feger D., Kubbutat M., Aly A. H., Proksch P., J. Nat. Prod., 77, 218-226 (2014).

4) Hirsch S., Rudi A., Kashman Y., Loya Y., J. Nat. Prod., 54, 92-97 (1991).

5) Urban S., Capon R. J., J. Nat. Prod., 55, 1638-1642 (1992).

6) Ciavatta M. L., Lopez Gresa M. P., Gavagnin M., Romero V., Melck D., Manzo E., Guo Y. W., van Soest R., Cimino G., Tetrahedron, 63, 1380-1384 (2007).

7) Utkina N. K., Denisenko V. A., Krasokhin V. B., J. Nat. Prod., 73, 788-791 (2010)

8) Pérez-García E., Zubía E., Ortega M. J., Carballo J. L., J. Nat. Prod., 68, 653-658 (2005).

9) McNamara C. E., Larsen L., Perry N. B., Harper J. L., Berridge M. V., Chia E. W., Kelly M., Webb V. L., J. Nat. Prod., 68, 1431-1433 (2005).

10) Gordaliza M., Mar. Drugs, 8, 2849-2870 (2010).

11) Jiao W.-H., Huang X.-J., Yang J.-S., Yang F., Piao S.-J., Gao H., Li J., Ye W.-C., Yao X.-S., Chen W.-S., Lin H. W., Org. Lett., 14, 202-205 (2012)

12) Du L., Zhou Y.-D., Nagle D. G., J. Nat. Prod., 76, 1175-1181 (2013). 
13) Jiao W.-H., Xu T.-T., Yu H.-B., Mu F.-R., Li J., Li Y.-S., Yang F., Han B.-N., Lin H.-W., RSC Adv., 4, 9236-9246 (2014).

14) Utkina N. K., Veselova M. V., Chem. Nat. Compd., 26, 37-40 (1990).

15) Shen Y.-C., Hsieh P. W., J. Nat. Prod., 60, 93-97 (1997).

16) Kondracki M. L., Guyot M., Tetrahedron, 45, 1995-2004 (1989).

17) Frisch M. J., Trucks G. W., Schlegel H. B., Scuseria G. E., Robb M. A., Cheeseman J. R., Scalmani G., Barone V., Mennucci B., Petersson G. A., Nakatsuji H., Caricato M., Li X., Hratchian H. P., Izmaylov A. F., Bloino J., Zheng G., Sonnenberg J. L., Hada M., Ehara M., Toyota K., Fukuda R., Hasegawa J., Ishida M., Nakajima T., Honda Y., Kitao O., Nakai H., Vreven T., Montgomery J. A. Jr., Peralta J. E., Ogliaro F., Bearpark M., Heyd J. J., Brothers E., Kudin K. N., Staroverov V. N., Kobayashi R., Normand J., Raghavachari
K., Rendell A., Burant J. C., Iyengar S. S., Tomasi J., Cossi M., Rega N., Millam J. M., Klene M., Knox J. E., Cross J. B., Bakken V., Adamo C., Jaramillo J., Gomperts R., Stratmann R. E., Yazyev O., Austin A. J., Cammi R., Pomelli C., Ochterski J. W., Martin R. L., Morokuma K., Zakrzewski V. G., Voth G. A., Salvador P., Dannenberg J. J., Dapprich S., Daniels A. D., Farkas O., Foresman J. B., Ortiz J. V., Cioslowski J., Fox D. J., Gaussian 09, Revision B.01, Gaussian, Inc., Wallingford, CT, U.S.A., 2010.

18) van Klink J. W., Larsen L., Perry N. B., Weavers R. T., Cook G. M., Bremer P. J., MacKenzie A. D., Kirikae T., Bioorg. Med. Chem., 13, 6651-6662 (2005).

19) Subramani R., Kumar R., Prasad P., Aalbersberg W., Retheesh S. T., Asian Pacific Journal of Tropical Biomedicine, 3, 291-296 (2013). 